\title{
Challenges of Good Governance in the European Union
}

\author{
Magdalena Michalak*
}

\begin{abstract}
* JUDr. Magdalena Michalak, PhD, Assistant Professor at the Department of Administrative Law and Procedure, Faculty of Law and Administration, University of Szczecin. (e-mail: m.michalak. amb@gmail.com)
\end{abstract}

The reviewed book, Challenges of Good Governance in the European Union, was issued under the scientific edition of Robert Grzeszczak, Professor at the University of Warsaw, Faculty of Law and Administration. It constitutes an outcome of cooperation of many authors who have prepared respective chapters of the book. It deals with a particularly important subject which is good governance and its today's challenges.

Currently, the issue of good governance at the European Union level is especially worth analysing, taking into account that the EU finds itself in a period of difficult reforms which shall allow to answer questions on its future shape and a chosen level of integration of the EU Member States. These reforms are also supposed to address the current economic and political crises which the EU is facing due to the lack of vision of integration and incapability to reconcile the interests of the Member States, which seem diverse and heterogeneous as never before. It is worth noticing that the EU's capacity to fulfil the needs of its citizens decreases and, at the same time, the democratic deficit within the European Union seems to increase.

The EU system at the time of the crisis also faces the problem of lack of stable longterm governance policy and emerging ad hoc decisions, which results inter alia from the already mentioned insufficiencies in the integration scheme. Such situation requires not only defining or redefining the goals of the European Union, but also a deep and balanced reflection, including the academic one, on the values the system should be based on and on a possible path of the EU development. The research on potential directions of the political and legal system's reforms led to the development of a concept of good governance, which, according to some scholars, including the authors of the reviewed book, may contribute to healing the EU order and therefore the principles of good governance should be introduced therein. According to the European Commission, good governance in the European Union shall be based on 5 principles: openness and transparency of the European institutions; participation of citizens in drafting and implementation of policies; accountability of each party involved in the decision-making process; effectiveness of the EU policies and coherence between them.

It must be noted that good governance may be seen as a value itself, but its full meaning and possible implications may become more clearly visible when we examine it in a particular context, from a perspective of other values and interests. Such operation may 
be done inter alia through its thorough analysis carried out in juxtaposition with democratic principles and the rule of law, human and civil rights, in particular the right to good administration, effectiveness of public administration or of judicial protection of individuals. The reviewed book is devoted to the above-mentioned concept of good governance and related challenges emerging at the European Union level. Good governance is analysed therein from different points of view using diverse approaches. The authors examine good governance as such and juxtapose it with other concepts and elements of the system of public administration.

The book was issued in 2016 by the publishing house Nomos, Baden-Baden. It consists of 3 parts, each of them divided into chapters (from 5 to 7 ). The book starts with a scientific editor's introduction to the subject tackled. The author presents and explains therein the origin of the concept of good governance, points out and elaborates on its persistence, but also on the ambiguities related to this notion and the development of the concept of good governance itself. The introductory part defines the objectives of the book which are to verify the hypothesis that the 21st century is a time of transition from government to governance; to analyse issues which constitute the concept of good governance in the $\mathrm{EU}$; to evaluate a hypothesis that an element of good governance is the ability to fulfil social needs of EU citizens; to determine optimal measures for wielding power and to formulate a coherent concept of good governance and methods of its realisation in practice. In the first part of the book the authors analyse the problematics of a change of the paradigms that is said to be taking place in the European Union system, which is defined as a transformation from government to good governance. Reflections presented therein discuss issues regarding inter alia different approaches to good governance in the European Union or links and relations between good governance and public administration as well as between good governance and human rights, with a special emphasis on the right to good administration. The second part is devoted to different questions concerning public participation and government effectiveness and relations between them. It includes chapters referring to the issues such as the concept of $\mathrm{EU}$ citizenship, rights and interests of EU citizens, their security level assured by the EU legal system, as well as access to e-justice. The third part of the book deals with problematics of the practice of good governance and it includes diverse case studies of such practice at both - EU and national level.

The subject addressed and reflections presented in the reviewed book are interesting from both - theoretical and practical point of view. Taking into account the first aspect, the book develops a survey of past debates concerning the concept of good governance and adds new thoughtfully developed insights therein. Secondly, it answers to practical needs associated with two phenomena i.e. the emergence of new legal regulations on the one hand and new needs of modern society on the other, which together leads to the appearance of new challenges for administration - after the formulation of a concept of good governance and methods of its realisation in practice the authors propose to introduce an approach based on a principle of good governance into the EU system. It shall be clearly underlined, as it is explained by the book's scientific editor himself in the introductory part, that the book focuses not on a question as to who governs, but rather how the 
governing is done. Such a view is undoubtedly valuable and deserves to be familiarised with.

Some of the issues undertaken in the study are of a general nature and may constitute the basis for more advanced research, while others are characterised by a fairly profound level of detail. Most considerations, though not all, are devoted to the concept of good governance in the EU context. However, many of them, even if they do not directly discuss national systems, are also depicted through examples of the impact the EU norms and practice have on them. Another advantage of the book are numerous references to literature and normative acts, which allows the reader to deepen the knowledge about such a complicated issue as good governance and problems related thereto.

The book Challenges of Good Governance in the European Union will be valuable and enriching to all readers interested in issues related to the functioning of the administrative apparatus, but also to the state and its structures as well as to the European Union in general. Given the issues raised by the authors, the book can be recommended to theoreticians and practitioners dealing with the problems of all legal and political systems - from national, through European to international level. It offers insights for researchers, academic teachers, practitioners, as well as opens a path to generate new discussions. 


\section{References}

1. Robert Grzeszczak (ed.), Challenges of Good Governance in the European Union, 369 pages. (Baden-Baden, Nomos, 2016). https://doi.org/10.5771/9783845275451 